Ks. Józef Pochwat MS*

Kraków

\title{
SYNTEZA TEMATYKI OPĘTANIA I EGZORCYZMU W DZIEŁACH SULPICJUSZA SEWERA
}

Stowa kluczowe

opętanie, egzorcyzm, egzorcysta, demon, zły duch, modlitwa, mnich Treść

I. Uwolnienie z opętania

II. Egzorcyzmy

W natłoku różnych informacji docierają do nas i te, które mówią o faktach opętania i potrzeby, aby w takiej sytuacji, korzystać z interwencji osób kompetentnych. Nie są to rzeczy dotąd nieznane, ponieważ jest o nich mowa zarówno w Starym (por. np. Iz 13, 21; 34, 14; Kpł 16, 10; Tb 3, 8; 6, 8. 14; Ba 4, 7), jak i Nowym Testamencie (por. np. Mt 4, 11; 12, 22; J 12, 31; Mk 1, 23-27. 34-39; 5, 14-2; 7, 22; 9, 38; Łk 8, 2). Na przełomie wieku IV i V w Galii w wyniku występowania takich przypadków, potrzebny był urząd egzorcysty. Wspomina o tych faktach w swoich pismach Sulpicjusz Sewer (ok. 360-420)1, autor biografii św. Marcina z Tours i kilku innych dzieł².

W niniejszym przedłożeniu mam na uwadze przede wszystkim oryginalny przekaz tematyki opętania i egzorcyzmów obecnej w pismach Sulpicjusza Sewera.

* Ks. Józef Pochwat MS, dr teologii w zakresie patrologii i historii dogmatu, autor i thumacz książek i artykułów z zakresu patrologii i życia duchowego.

1 Obszerne biografie Sulpicjusza Sewera, opracowali już np. Ghislaine de Senneville-Grave, w: Introduction, Sulpice Sévère, Chroniques, SCh 441, Paris 1999, s. 7-68; M. Starowieyski, Wstep w: Sulpicjusz Sewer, Pisma o św. Marcinie z Tours, thum. P. J. Nowak, wst. kom. i opr. M. Starowieyski, ŹM 8, Kraków 1995, s. 11-46; J. Pochwat, Sulpicjusz Sewer i jego dzieło w czasie przemian dziejowych w Galii na przełomie IV i V wieku, [w:] Starożytny chrześcijanin w obliczu przemian dziejowych, Teologia Patrystyczna, t. 8, Poznań 2011, s. 65-102.

2 Dzieła Sulpicjusza Sewera to: Życie św. Marcina, Dialogi i Listy, [w:] Sulpicjusz Sewer, Pisma o św. Marcinie z Tours, przekł. P. J. Nowak, wstęp, kom. i oprac. M. Starowieyski, Źródła Monastyczne, nr 8 [dalej: ŹM 8], Kraków 1995 i Kroniki [w:] Sulpice Sévère, Chroniques, SCh 441, Paris 1999. 
Stąd moją intencją jest przeprowadzenie źródłowej syntezy wyżej wymienionych zagadnień, jednak bez dokonywania ich krytycznej oceny.

\section{UWOLNIENIE Z OPĘTANIA}

Sulpicjusz Sewer uważa, że demon ma moc wchodzenia w ciało człowieka. Przebywając w nim sieje strach zewnętrznymi oznakami (np. zgrzytanie zębów). Ukazuje św. Marcina, który wyrzucił demona:

„W tym samym czasie i w tymże mieście wszedłszy do domu pewnego ojca rodziny, zatrzymał się na progu mówiąc, że widzi w przedsionku strasznego demona. Gdy mu rozkazał, aby wyszedł, ten pochwycił kucharza ojca rodziny, który przebywał w dalszej części budynku, tak że biedak zaczął zgrzytać zębami, gotów zszarpać każdego, kto by mu wszedł w drogę. Cały dom był tym wstrząśnięty, rodzina przerażona, lud gotowy do ucieczki. Marcin rzucił się naprzeciw szalejącemu i najpierw rozkazał mu stanąć. Lecz gdy ten zgrzytał zębami i groził rozdziawionymi ustami, że go ugryzie, Marcin włożył mu palce do ust i rzekł: «Jeśli masz jakąś moc - pożryj je». Wtedy jednak, jakby ktoś wprowadził opętanemu do ust rozpalone do białości żelazo, szeroko rozwarłszy zęby unikał dotknięcia palców błogosławionego męża. A gdy demon mękami i udrękami został w końcu zmuszony do ucieczki z opętanego ciała, nie pozwolił mu wyjść przez usta: został wyrzucony «przez odbyt», pozostawiając po sobie obrzydliwe ślady płynów z wnętrzności"’3.

Biograf zauważył, że moc Marcina przejawiała się poprzez kontakt osoby opętanej przez demona z tym, czego on dotykał. Wiązka słomy, na której siedział święty zawieszona na szyi opętanego duchem błędu, wyrzuciła demona i uzdrowiła człowieka ${ }^{4}$.

Sulpicjusz Sewer ubolewał nad faktem niedowierzania ludzi w cuda zdziałane przez św. Marcina, tym bardziej, że w cuda te wierzyły demony. Ryk opętanych w kościele towarzyszył Marcinowi, gdy ten wypędzał z nich demony. Sposób, w jaki to czynił różnił się od sposobów stosowanych przez innych egzorcystów. Marcin nie dotykał opętanego rękami, ani nie krzyczał. W taki sposób działali

3 Sulpicjusz Sewer, Pisma..., Żywot św. Marcina, 17, 5-7, ŹM 8, s. 73-74.

4 Sulpicjusz Sewer, Pisma..., Dialog drugi, 8, 6-9, ŹM 8, s. 156-157: „Gdy widzę tę słomę, przygotowaną na nasze posłania, przywodzi mi to na myśl, że Marcin nawet przez słomę, na której spoczywał, ukazywał działanie swojej mocy. Było to tak: Na pograniczu Biturigów i Turonów leży wioska Claudiomagus; Kościół tamtejszy słynie z pobożności wiernych i nie mnie z chwalebnie wielkiej liczby dziewic konsekrowanych. Przechodząc tamtędy Marcin znalazł schronienie w zakrystii kościoła. Po jego odejściu wpadły do tej zakrystii wszystkie dziewice całując miejsca, na których siedział albo stał błogosławiony mąż, i rozdzielając «między siebie» słomę, na której spoczywał. Po kilku dniach jedna z nich zawiesiła część słomy, jaką sobie pozbierała dla błogosławieństwa, na szyi opętanemu, którego dręczył duch błędu. Bez zwłoki, szybciej niż trwa wymówienie jednego słowa, demon został wyrzucony, a opętany człowiek doznał uzdrowienia". 
inni duchowni. Marcin wypraszał wszystkich i sam modlił się na środku kościoła w pozycji krzyża, rozciągając się na posadzce, ubrany we włosiennicę z głową posypaną popiołem (oznaki pokory i uniżenia, wręcz pokuty). Wówczas można było widzieć te nieszczęśliwe osoby, które były dręczone przez złe duchy. Opętani dręczeni w sumieniu, sami na głos wyznawali swoje grzechy. Demony niepytane ujawniały swoje imiona: Jowisz, Merkury, czyli imiona bóstw pogańskich ${ }^{5}$. Sulpicjusz podaje ważną informację, otóż jego zdaniem demony, słudzy diabła, którego nazywa ich przywódcą nie tylko dręczyli swoje ofiary, ale sami byli udręczeni ${ }^{6}$. Hagiograf ubolewał nad tym, że chrześcijanie nie chcieli wierzyć w cuda św. Marcina, podczas gdy czyniły to demony. Marcin ciągle miał do czynienia z ludźmi opętanymi, którzy gromadzili się w kościele niedaleko jego klasztoru. Z opisu Sulpicjusza dowiadujemy się, że „opętani ryczeli na cały głos i drżeli na podobieństwo skazańców oczekujących przyjścia sędziego"”. Ważnym jest spostrzeżenie Sewera, który opisał sposób postępowania Marcina egzorcysty z ludźmi opętanymi przez złe duchy oraz zachowanie opętanych w spotkaniu ze świętym:

„Ile razy Marcin brał na siebie trud wypędzania demonów z opętanych, żadnego z nich nie dotykał rękami, na żadnego nie krzyczał, jak zazwyczaj czynią to duchowni, używający wielu słów. On, po przyprowadzeniu opętanych, rozkazywał, aby pozostali odeszli i modlił się samotnie przy zamkniętych drzwiach na środku kościoła, rozciągnięty na ziemi, ubrany we włosiennicę i posypany popiołem. Wtedy jednak widać było nieszczęsnych, jak bardzo byli dręczeni na różne sposoby: jedni unosili się w powietrzu do góry nogami, jakby zwisali z chmury; szaty ich jednak nie spadały im na dół, aby nie uraził wstydliwości widok obnażonych części ciała; innych słyszało się, jak dręczeni w sumieniu i nawet nie pytani o cokolwiek, wyznawali swoje występki"».

Sulpicjusz przedstawił Marcina, który rozkazywał ogniowi, dzikim zwierzętom, przede wszystkim jednak uwalniał ludzi opętanych przez duchy nieczyste. Nasz Autor uważał, że sposobem na duchy nieczyste jest potęga słowa. Sewer podaje świadectwo mówiące, że włókienka z włosiennicy Marcina miały moc uwalniania z mocy duchów nieczystych. Marcin według Sulpicjusza miał codziennie kontakt z aniołami, rozmawiał z nimi. Św. Marcin widział zatem rzeczy niewidzialne extra corpus, był ekstatykiem ${ }^{9}$. Moc św. Marcina przy uzdrawianiu

5 Sulpicjusz twierdzi, że św. Marcin „,najwięcej wycierpiał ze strony zaczepnego Merkurego. Jowisz - mówił - jest ociężały i tępy. Rzeczy te częstokroć wydawały się niewiarygodne nawet mnichom mieszkającym w tym samym klasztorze - o ileż więc bardziej spodziewam się, że wszyscy inni, którzy o nich usłyszą, nie uwierzą" (Sulpicjusz Sewer, Pisma..., Dialog drugi, 13, 6-7, ŹM 8, s. 163; por. Sulpicjusz Sewer, Pisma..., Dialog trzeci, 6, 4, ŹM 8, s. 173).

6 Por. Sulpicjusz Sewer, Pisma..., Dialog trzeci, 6, 5, ŹM 8, s. 173.

Sulpicjusz Sewer, Pisma..., Dialog trzeci, 6, 2, ŹM 8, s. 173.

8 Sulpicjusz Sewer, Pisma..., Dialog trzeci, 6, 3-4, ŹM 8, s. 173.

9 Sulpicjusz Sewer, Pisma..., Dialog pierwszy, 25, 1-3, ŹM 8, s. 139-140: „Jeśli bowiem budzi podziw, że owego Egipcjanina nie tknął płomień, to również Marcin wielokrotnie rozka- 
opętanego ujawniała się także jeszcze zanim tenże przekroczył próg klasztoru zamieszkanego przez niego ${ }^{10}$.

Sulpicjusz Sewer ukazał świętego pustelnika obdarzonego władzą wypędzania złych duchów, bowiem władza wypędzania duchów ciemności jest darem. Nasz Autor wskazuje na sposoby uzdrawiania opętanych ciał: fizyczna obecność egzorcysty (w wyjątkowych sytuacjach obecność ta nie była konieczna), wypowiadane przez niego słowa, za pomocą nitek z włosiennicy lub pisanymi i wysyłanymi przez niego listami. Po ratunek przychodzili ludzie z całego świata, biedni i tak zwani wielcy tego świata: prefekci, sędziowie, a nawet biskupi. Opętanym towarzyszyła czasem wiara w dotknięcie ręki lub szaty świętego mnicha, która sprawiała uświęcenie i oświecenie Bożym darem.

Biograf Marcina pokazał, że nawet mnich może ulec próżności, nie móc nad nią zapanować i mieć tego świadomość, że próżność w nim jest. Demony bowiem umiejętnie wykorzystują każdy słaby punkt człowieka, podsycają problem, bowiem nagłaśniając imię mnicha, ugruntowywali jego próżność. Próżność Sulpicjusz nazywał trucizną rozlaną w sercu. Mnich nie był w stanie sam sobie pomóc, mimo to, że innym pomagał, dlatego wyprasza u Boga, aby diabeł zawładną nim na pięć miesięcy, chcąc upodobnić się do tych, których wcześniej uzdrawiał. Demon porywa mnicha i skuwa kajdanami. Oznacza to, że diabeł odbiera człowiekowi wolność, którą ma on daną od Boga. Opętanie zatem to zniewolenie (ubezwłasnowolnienie) człowieka przez szatana. Mnich zniósł wszystko to, co zwykli cierpieć opętani. Po pięciu miesiącach nastąpiło uwolnienie mnicha od demona i próżności ${ }^{11}$.

Sulpicjusz Sewer opisał sytuację, w której Marcin widział dwa demony, które podburzały Brykcjona ${ }^{12}$. Brykcjon złorzeczył Marcinowi, który upomniał go, że trzymał konie i nabywał niewolników. Zarzucano mu, że zakupił piękne dziewczęta. Demony podjudziły Brykcjona, który napadł na Marcina. Postawa Marcina: łagodne oblicze, spokój ducha, miłe słowa skierowane do agresora, aby go

zywał ogniowi. Jeżeli wspomnisz, że anachoretom dzikie zwierzęta kładły się do nóg, to on też oswajał aż do granic poufałości wściekłe bestie i jadowite węże. Jeżeli zaś porównasz go z tym, który uwalniał opętanych przez duchy nieczyste potęgą słowa albo nawet mocą włókienek, to istnieją liczne przykłady na to, że Marcin z pewnością także w tej dziedzinie nie był gorszy. A jeśli znowu powołasz się na przykład owego pustelnika, który, okryty swoimi włosami zamiast ubrania, był - jak przypuszczano - odwiedzany przez aniołów, to przecież z Marcinem także codziennie rozmawiali aniołowie".

10 Sulpicjusz Sewer, Pisma..., Dialog trzeci, 14, 1, ŹM 8, s. 182: „Lecz, jak tego doświadczyliśmy, pomnożonymi zasługami całkowicie naprawił pomniejszoną chwilowo łaskę. Widziałem później, jak przyprowadzono do tylnej furtki jego klasztoru opętanego, który został uzdrowiony zanim jeszcze dotknął progu".

11 Por. Sulpicjusz Sewer, Pisma..., Dialog pierwszy, 20, 1-9, ŹM 8, s. 133-134.

12 M. Starowieyski w podaje, że Brykcjon, który był następcą św. Marcina z Tours, początkowo był jego przeciwnikiem. Złożony z urzędu z powodu oszczerstw, powrócił na tron biskupi i umarł w opinii świętości, por. Sulpicjusz Sewer, Pisma ..., Dialog trzeci, ŹM 8, s. 183. 
powściągnąć. Duch nazwany nikczemnym podburzył Brykcjona. Metoda działania demona: słowami wypowiedzianymi przez Brykcjona udowadnia, że ten jest na wyższym stopniu świętości, uznaje się za lepszego, powołuje na wychowanie w klasztorze, zarzuca pogardę do spraw wojskowych, dziwactwa na starość, egzorcyzmy określa jako zabobony, widzenia demonów jako śmieszności. Wówczas gdy Marcin odpędza demony modlitwą, wówczas Brykcjon prosi o przebaczenie. Ciekawe, że Brykcjon miał świadomość, że był omotany przez złego ducha. Marcin nie przychylił się do pozbawienia godności kapłańskiej Brykcjona dlatego, aby nikt nie zarzucił mu, że się na nim mści ${ }^{13}$.

Sulpicjusz uważał, że demon nie zawsze działa w pojedynkę. Potrafi wywołać wśród ludzi lęk. Jednakże w świątyni chrześcijańskiej demon traci swą moc:

„W międzyczasie miasto przeraziła nagła wieść o ruchach i natarciu barbarzyńców. Marcin polecił przywieść do siebie opętanego i rozkazał mu, aby powiedział, czy ta wiadomość jest prawdziwa. Wtedy ten wyznał, że było z nim dziesięciu demonów, którzy rozszerzali tę pogłoskę wśród ludzi, aby przynajmniej trwoga wypędziła Marcina z tego miasta: w rzeczywistości barbarzyńcy nawet nie myślą o napadzie. Tak więc, kiedy duch nieczysty wyznał to pośrodku kościoła, miasto zostało uwolnione od panującej trwogi i przerażenia"14.

Sulpicjusz Sewer przyjmował jako rzecz naturalną fakty opętania człowieka przez demony. Człowiekiem opatrznościowym przy uwalnianiu ludzi od wpływu duchów ciemności był św. Marcin z Tours, który wyrzucał je na różnego rodzaju sposoby. Wykazuje jednocześnie, że wszyscy bez wyjątku mogą dostać się pod zgubny wpływ szatana.

Opętanie zdaniem Sulpicjusza Sewera jest związane z obecnością złego ducha w człowieku. Sewer jednoznacznie stwierdza przypadki zawładnięcia ciałem człowieka przez demona. Skoro demon ucieka z ciała człowieka to znak, że musiał w nim wcześniej przebywać. Sulpicjusz przekazuje ważną informację, dotyczącą tego, że demon nie chce opuścić ciała człowieka, którego opętał. Potrzeba dopiero skutecznej interwencji ze strony egzorcysty, aby go zmusił do wyjścia z osoby opętanej.

Interesującym jest spostrzeżenie Sulpicjusza Sewera, który wyraźnie odwołuje się do sumienia osób dręczonych. Znak to, że opętani ponoszą odpowiedzialność za dopuszczenie do siebie złego ducha, stąd też ich prawidłową reakcją było wyznanie własnych grzechów. Cenną informacją przekazaną przez biografa św. Marcina jest to, że demony spontanicznie wyjawiały swoje imiona oraz to, że dręczyły ludzi, których opętały. Znamiennym w przekazie Sulpicjusza jest stwierdzenie, że demony były sprawcami udręczenia opętanych przez nich ludzi, ale i to, że one same doznawały udręczenia.

13 Por. Sulpicjusz Sewer, Pisma..., Dialog trzeci, 15, 1-7, ŹM 8, s. 183-185.

14 Sulpicjusz Sewer, Pisma..., Żywot św. Marcina, 18, 1-2, ŹM 8, s. 74. 
Z opisów przekazanych przez biografa Marcina wynika, że na opętanie przez złego ducha może narazić się każdy bez wyjątku człowiek. Sulpicjusz Sewer podprowadza czytelnika do odkrycia sedna sprawy, czyli stwierdzenia, że jedynie w Bogu zagwarantowana jest wolność człowieka. Odwrócenie się od Niego ukierunkowuje człowieka ku szatanowi, który mu tę wolność zabiera i czyni swoim niewolnikiem. Sulpicjusz Sewer podkreśla, że zły duch może działać sam, ale bywają przypadki, kiedy działanie jego jest zwielokrotnione uczestnictwem większej ich ilości.

\section{EGZORCYZMY}

Sulpicjusz Sewer wiedział, że św. Marcin cieszył się towarzystwem aniołów. Wejście w kontakt z towarzystwem o niskim poziomie moralnym, według opinii Marcina, spowodowało mniejszą jego skuteczność przy dokonywaniu egzorcyzmów uzdrawiania niektórych opętanych ${ }^{15}$. Dzięki biografowi Marcina otrzymujemy cenne świadectwo o istniejącym w Kościele IV wieku urzędzie egzorcysty. Sulpicjusz na przykładzie Marcina określa przymioty egzorcysty mówiąc, że pokora, przeciwieństwo próżnej chwały, to jedna z broni w jego walce z szatanem ${ }^{16}$.

Św. Marcin według Sulpicjusza miał władzę nad okrutnym władcą Awicjanem ${ }^{17}$, który nie ośmielił się wyrządzić krzywdy swoim podwładnym w miejscu zamieszkania przez świętego, czyli w Tours. Marcin miał także dar widzenia demona. Widząc

15 Sulpicjusz Sewer, Pisma..., Dialog trzeci, 13, 3-6, ŹM 8, s. 181: „W pobliżu wsi o nazwie Andethanna, w miejscu gdzie niezmierne zacisze leśne pozwala na odosobnienie, pozostał trochę z tyłu za swymi towarzyszami i usiadł, roztrząsając dokładnie w myślach przyczynę swego smutku oraz fakty oskarżające go i broniące. Nagle stanął przy nim anioł. «Marcinie - rzekł - słusznie odczuwasz wyrzuty, lecz nie miałeś innego wyjścia. Odnów moc, zdobądź się znowu na stanowczość, abyś nie naraził na szwank już nie tylko twojej chwały, lecz także zbawienia». Od tamtego czasu wystrzegał się pilnie kontaktów ze stronnictwem Itacjusza. Ponadto wyznał nam szczerze przy uzdrawianiu niektórych opętanych, dokonującym się wolniej i z większym trudem niż zazwyczaj, że to z powodu owej nieszczęsnej wspólnoty, mimo iż wszedł w nią tylko pod naciskiem chwilowej konieczności, a nie z przekonania, utracił część swej mocy. Żył potem jeszcze szesnaście lat. Nie udał się na żaden synod i trzymał się z daleka od wszystkich zebrań biskupów”.

16 Sulpicjusz Sewer, Pisma..., Żywot św. Marcina, 5, 2, ŹM 8, s. 58: „Hilary próbował powiązać go ściślej ze sobą przez udzielenie mu stopnia diakona i tak związać go ze służbą Bożą. Ponieważ jednak wielokrotnie się opierał wołając, że jest niegodny, ów mąż wielkiej mądrości pojął, iż może go ująć w jeden tylko sposób: jeśli da mu taki urząd, który wydawałby się poniżającym*. Tak więc zdecydował, że ma zostać egzorcystą. Tej posługi Marcin już nie odrzucił, aby nie wydawało się, że wzgardził nią jako najniższą”. *Czytamy następujące wyjaśnienie: „Hilary pragnął silniej związać Marcina z Kościołem w Poitiers poprzez diakonat, ale Marcin uważał się za niegodnego tego stopnia. Udzielenie stopnia egzorcysty człowiekowi starszemu, który miał już swoją pozycję społeczną, mogło być uznane za poniżające. Podkreślenie jednak tego stopnia jest charakterystyczne, gdyż całe życie Marcina poświęcone jest walce z szatanem" (Sulpicjusz Sewer, Pisma..., Żywot św. Marcina, ŹM 8, s. 58; por. I. Gobry, Les moines en Occident, 2, Paris 1981, s. 91).

17 Awicjan - Claudius Avitianus, sprawował różne wysokie urzędy (wikariusz w Afryce w latach 362-363), następnie został zesłany do Galii, gdzie odznaczał się wielkim okrucieństwem, por. Sulpic- 
go siedzącego na grzbiecie tyrana, dokonał egzorcyzmu, wypędzając demona. Uczynił to „chuchnięciem”, co jak podaje tłumacz, było częścią egzorcyzmu dokonującego się w czasie chrztu świętego. Uwolniony od wpływu demona Awicjan stał się łagodniejszy. Demon nazwany jest duchem nieczystym. Ciekawie Sulpicjusz rzecz ujmuje pisząc, że być może demon nie miał nad Awicjanem więcej władzy, dlatego, że służący mu Awicjan zawstydził się z jego powodu. Może raczej bardziej chodziło o to, że Awicjan, który podlegał rozkazom demona, dostrzegł, że Marcin miał wyższą władzę, skoro rozkazał demonowi, a ten był mu posłuszny ${ }^{18}$.

Sulpicjusz Sewer opisał także inny sposób niż zaprezentowane „chuchnięcie”. Marcin miał moc wyrzucenia ducha nieczystego z poganina przez włożenie nań ręki. Działanie demona w opętanym wyrażało się na zewnątrz przez złość i zgrzytanie zębami:

„W owym czasie był dręczony śmiertelnymi mękami opanowany przez demona sługa pewnego prokonsula Tetradiusza. Poproszono przeto Marcina, aby położył na nim rękę. On kazał go do siebie przyprowadzić. Lecz nikczemny duch w żaden sposób nie pozwolił się wyprowadzić z pokoju, w którym się znajdował: tak bardzo wściekał się i zgrzytał zębami na wchodzących. Wówczas Tetradiusz rzucił się do nóg błogosławionego męża z błaganiem, aby on sam przyszedł do domu, w którym przebywał opętany. Marcin jednak odmówił wyjaśniając, że nie może wejść do bezbożnego i pogańskiego domu. Tetradiusz był bowiem w tym czasie jeszcze nieprzejednanym zwolennikiem pogańskiego błędu. Tamten przyrzekł zatem uroczyście, że jeżeli demon zostanie wypędzony z jego sługi, to on stanie się chrześcijaninem. Tak więc Marcin, położywszy rękę na owym słudze, wyrzucił z niego ducha nieczystego" 19 .

Czasem potrzeba było długiego czasu, aby uwolnić człowieka od zgubnego wpływu demonów. Sulpicjusz Sewer opisuje zdarzenie, gdy pewien żołnierz

jusz Sewer, Pisma ..., Dialog trzeci, ŹM 8, s. 170, przyp. *; J. den Boeft, J. W. Drijvers, D. den Hengst, Philological and historical commentary on Ammianus Marcellinus XXVII, Leiden 2009, s. 162.

18 Sulpicjusz Sewer, Pisma..., Dialog trzeci, 8, 1-3, ŹM 8, s. 175: „Ale pozwólcie, że powrócę do Awicjana: podczas gdy w całej okolicy i we wszystkich miastach dawał on odrażające dowody swego okrucieństwa, tylko w Tours nie popełnił żadnej zbrodni. Owa bestia, która syciła się ludzką krwią i śmiercią wielu nieszczęśliwych, w obecności błogosławionego męża okazywała się łagodną i spokojną. Pamiętam, że pewnego dnia przybył do niego Marcin. Wszedłszy do jego pokoju ujrzał demona niezwykłej wielkości siedzącego na jego grzbiecie. Z daleka więc - użyjmy z konieczności tego słowa, choć jest ono mało poprawne - «chuchnął» (część egzorcyzmu w czasie chrztu, przyp. tłum.) na niego. Awicjan sądząc, że to na niego tchnął, odezwał się: «Czemuż to, święty ojcze, tak mnie traktujesz?» Wtedy Marcin odpowiedział: «Nie ciebie, lecz tego obrzydliwca, który spoczywa na twoim karku». Demon odszedł opuściwszy tego rodzaju fotel, do którego się przyzwyczaił. Wiadomo powszechnie, że od tego dnia Awicjan stał się łagodniejszy. Może dlatego, że pojął, iż do tej pory pełnił zawsze wolę siedzącego na nim diabła, lub też dlatego, że duch nieczysty, przepędzony przez Marcina ze swego miejsca, utracił moc wyrządzania szkód. Ponieważ sługa zawstydził się z powodu swego pana, pan już nie gnębił swego sługi” (por. na ten temat: P. G. van der Nat, Geister [Dämonen], RACh IX, Stuttgart 1976, s. 750).

19 Sulpicjusz Sewer, Pisma..., Żywotśw. Marcina, 17, 1-4, ŹM 8, s. 73. 
zostaje mnichem i nabywa cnoty dorównujące doskonałością innych mnichom. Jest wytrzymały w postach, wyróżnia się pokorą, stały w wierze. Podejmuje myśl, którą podsuwa mu diabeł. Myśl sama w sobie była dobra, dotyczyła bowiem chęci zbawienia własnego syna z jego rodziną. Sulpicjusz upatruje w tym fałszywą sprawiedliwość. Mnich porzuca styl życia i swoją celę. Jest nieposłuszny opatowi, nie słucha rady innych mnichów, którzy odradzają mu to. Pozostaje uparty. Na to tylko czekał demon, który go opanował do tego stopnia, że mnich gryzł się własnymi zębami i toczył krwawą pianę z ust. W walce $\mathrm{z}$ demonem pomagają mu bracia, ale demon, duch nieczysty był niezwykle silny. Mnicha trzeba było skuć żelaznymi łańcuchami. Duch nieczysty opuścił go dopiero po dwóch latach, dzięki modlitwie świętych mnichów. Sulpicjusz Sewer konkluduje, że pozór fałszywej sprawiedliwości i chwiejna niestałość doprowadza do zgubnej lekkomyślności i porzucenia tego, co się raz zaczęło ${ }^{20}$.

Marcin, według relacji naszego Autora dbał o czystość wyznawanej wiary, o czystość kultu męczenników. Dla Sulpicjusza Sewera wiara i oddawanie czci rzeczom niepewnym, niesprawdzonym była zabobonem. Marcin miał niezwykłe właściwości oglądania duchów i rozmawiania z nimi. Rozmawiał nawet z duchem człowieka potępionego, na co wskazuje lewa strona, która jest synonimem grzechu i potępienia. Obecni słyszeli głos, ale tylko Marcin widział ducha, pozostali świadkowie tego wydarzenia nie mieli takiego daru. Św. Marcin uwolnił ludzi od zabobonu, od oddawania czci osobie potępionej tzn. pozostającej w szponach szatana. Sulpicjusz Sewer podprowadza czytelników do czystości wiary, sugerując, że należy zachować daleko posuniętą ostrożność, aby nie okazało się, że człowiek zamiast Boga czci szatana ${ }^{21}$.

Wielkość św. Marcina, jako egzorcysty polegała w dużej mierze na jego nieprzejednanej postawie przeciwko próżności i pyszałkowatości. Marcin uwalniał

20 Por. Sulpicjusz Sewer, Pisma..., Dialog pierwszy, 22, 1-5, ŹM 8, s. 136-137.

${ }^{21}$ Sulpicjusz Sewer, Pisma..., Żywot św. Marcina, 11, 1-5, ŹM 8, s. 67: „Niedaleko od miasta w pobliżu klasztoru znajdowało się pewne miejsce, które fałszywa ludzka opinia otoczyła famą świętości twierdząc, jakoby tam pochowano męczenników. Był tam nawet ołtarz, wzniesiony przez poprzednich biskupów. Lecz Marcin, niełatwo dając wiarę rzeczom niepewnym, domagał się od starszych wiekiem kapłanów czy kleryków, aby powiedzieli mu imię męczennika i czas jego męczeństwa. Ponieważ pamięć starszych nie przekazała nic pewnego, wzbudziło to w nim poważne wątpliwości. Trzymał się więc przez pewien czas z dala od tego miejsca, ani nie zabraniając oddawania czci, gdyż nie miał pewności, ani też nie użyczając tłumowi swego autorytetu, aby przypadkiem nie wzmógł się zabobon. Pewnego dnia poszedł na to miejsce wziąwszy ze sobą kilku braci. Następnie, stojąc nad grobem modlił się do Pana, aby mu objawił, kim jest i jakie ma zasługi pochowany tutaj człowiek. Nagle, obróciwszy się w lewo, ujrzał stojący w pobliżu żałosny, straszliwy cień. Rozkazał mu, aby powiedział swoje imię i zasługi. Tamten powiedział imię i wyznał swoją winę: był rozbójnikiem, został stracony za popełnione zbrodnie, mylnie czczony przez lud; nie ma nic wspólnego z męczennikami ani też z ich chwałą, gdyż on otrzymał «zasłużoną» karę. W przedziwny sposób ci, którzy byli tam obecni, słyszeli głos mówiącego, osoby jednak nie widzieli (por. Dz 9,7). Wtedy Marcin przedstawił im to, co widział, i rozkazał usunąć stojący w tym miejscu ołtarz. W ten sposób uwolnił lud od omamu tego zabobonu". 
od duchów nieczystych dworzan, prefektów, a nawet samych władców. Święty zwalczał nie tylko próżność, ale także okazję do okazywania próżności. Nigdy nie pozwolił sobie, aby przyjąć zacnego prefekta Wincentego, aby nie zrodziła się w nim jakakolwiek próżność czy duma ${ }^{22}$.

Sulpicjusz potwierdza istnienie w Kościele na przełomie IV i V wieku, urzędu egzorcysty. Podkreśla przy tym, że ważnymi przymiotami osób powołanych na ten urząd są pokora, sprawiedliwość i stałość postanowienia. Kładzie również mocny nacisk na czystość wyznawanej wiary. Przestrzega przed łatwowiernością i oddawaniem czci rzeczom niepotwierdzonym autorytetem Kościoła. Wykazuje, że stosunkowo łatwo wówczas o przejście z wiary (kult Boga), do zabobonu (kult szatana).

\section{PODSUMOWANIE}

Zestawiając opisy mówiące o możliwości wpływu złych duchów na człowieka, stwierdzamy stosunkowo dużą ilość danych na ten temat w pismach Sulpicjusza Sewera. Autor zafascynowany osobą św. Marcina, ukazał liczne przypadki opętania ludzi przez szatana. Jednakże Sewer nie zatrzymywał się tylko na stwierdzeniu takich faktów. Interesowało go bardziej to, że istnieje możliwość uwolnienia człowieka spod zgubnych wpływów demonów. Podkreślał zatem ważną rolę egzorcysty, człowieka, który ma moc wyrzucenia demona z ciała ludzkiego. Biograf Marcina wskazał dwa rodzaje egzorcystów. Pierwsi to ci, którzy mieli kontakt przez dotyk z opętanymi i oddziaływali na nich krzykiem. Rodzaj drugi był jedyny sam w sobie, gdyż jego wyłącznym przedstawicielem był św. Marcin. Jego postawa różniła się od pozostałych egzorcystów tym, że Marcin ani nie dotykał rękami opętanych, ani na nich nie krzyczał. Dla Sulpicjusza Sewera postać św. Marcina z Tours była ideałem egzorcysty. Jego najskuteczniejszą bronią była modlitwa,

22 Sulpicjusz Sewer, Pisma..., Dialog pierwszy, 25, 4-7, ŹM 8, s. 140-141: „Przeciwko zaś próżności i pyszałkowatości odznaczał się tak nieprzejednaną postawą, że nikt bardziej od niego nie gardził tymi wadami. Gdy uzdrawiał owładniętych przez duchy nieczyste, często czyniąc to także na odległość, rozkazywał nie tylko dworzanom albo prefektom, lecz nawet samym władcom. Nie czynił tego bynajmniej jedynie z powodu swoich cudów, lecz głównie dlatego, wierz mi, że nikt bardziej nie zwalczał nie tylko samej próżności, lecz również przyczyny oraz okazji do okazywania próżności. Powiem rzecz wprawdzie drobną, lecz nie należy i jej pominąć. Zasługuje bowiem na pochwałę ten, który piastując wysokie stanowisko miał tak zbożną wolę okazania szacunku błogosławionemu mężowi. Myślę o prefekcie Wincentym, mężu nadzwyczajnym, którego w całej Galii nikt nie przewyższa w cnotach wszelkiego rodzaju. Gdy przybywał on w okolice Tours, wielokrotnie prosił Marcina, aby mu przygotował gościnę w swoim klasztorze. Wzorował się w tym z pewnością na przykładzie błogosławionego biskupa Ambrożego, o którym się mówi, że raz po raz gościł przy stole u siebie konsulów i prefektów. Jednak Marcin nie chciał przyjmować u siebie męża wysoko urodzonego, aby z tego nie wykluła się jakaś próżność czy duma. Musisz więc przyznać, że Marcin posiadał cnoty tych wszystkich, których wyliczyłeś, oni zaś wszystkich cnót Marcina w sobie nie mieli". 
niezwykła świętość, pokora i ascetyczny styl życia, co sprawiało, że jego słowa w spotkaniu z demonem posiadały skuteczną moc.

Należy podkreślić, że Sulpicjusz jednoznacznie stwierdza, że władza wyrzucania złych duchów jest darem, czyli łaską od Boga. Mimo to, że wspomina on o mocy Chrystusa w czynach Marcina, to jednak można odnosić wrażenie, że dla Sulpicjusza Sewera na pierwszy plan wysuwa się postawa i zasługa świętego człowieka. Takie podejście może być niebezpieczne i zaciemniać najważniejszą osobę w walce z demonami - Syna Bożego Jezusa Chrystusa.

\section{POSSESION AND EXORCISM \\ IN THE WORKS OF SULPICIUS SEVERUS}

\section{Summary}

This article contains thoughts of Sulpicius Severus (ca 360-420) with regard to the influence of evil spirits on man. Based on the knowledge of St. Martin of Tours, who had much to do with demons. Sulpicius presented a number of human cases of demonic possession by an evil spirit. Most cases he described were about man's release from possession.

Sulpicius Severus was demonstrating that when Satan masters a man he takes away his freedom, a fundamental value, which comes from God. In the face of the numerous cases of enslavement of people by Satan, God's intervention was needed. Sulpicius was convinced that God has equipped some people to be exorcists, with the gift of releasing the possessed from the power of the devil.

Keywords

possession, exorcism, exorcist, the devil, demon, evil spirit, prayer, the monk. 